\title{
Evaluation of roles of auditors in the fraud detection and investigation in Nigerian industries
}

\author{
${ }^{1}$ Mary Josiah, ${ }^{1}$ Adediran A Samson, and ${ }^{2}$ Akpeti O Elizabeth \\ Igbinedion University Okada, ${ }^{1}$ Accounting Department and ${ }^{2}$ Department of Business \\ Administration College of management Sciences
}

\begin{abstract}
This Study focused on an analysis of the role of auditors in fraud detection: a survey of selected firms in Nigeria. The data collection technique used for this study is questionnaire and oral interview was also supportive. The data was analyzed through the use of chi-square, this findings of this work are that the firm's produced and published financial statement as well as engaging the services of auditors and that detection of fraud and errors is inevitable. And also, the case of fraud in these organizations is due to poor management, lack of internal auditors, poor internal control system and corruption. Based on these findings, it is recommended that selected firms should ensure continuous policies and strategies aimed at effective and efficient management. That management should continually engage the services of qualified and experienced external auditors which will not only put in place an effective internal control system but which will equally enhance it. Finally, education, proper enlightenment and above all self discipline is recommended to step down the level of corruption not only in selected firms but also in Nigeria as a whole.
\end{abstract}

\section{INTRODUCTION}

In our society where the business culture has been overridden in recent times with fraudulent practices penetrated by management and employees, the lack of clear understanding of the duties of an auditor in relation to fraud detection has often led to unjustifiable criticisms of his role. Auditors are known to be competent, honest and independent professionals who express unbiased opinion on the truth and fairness of the financial statement as presented by management to members of the company. The accounting profession has over the years built a reputation, which encourages others to rely upon the opinions auditors express. If these opinions are unclear or even unreliable, serious consequences may and indeed have resulted.

\section{OBJECTIVES OF THE STUDY}

The objectives of the study includes:

i. To determine the role of the auditors in Fraud Detection.

ii. To address the erroneous belief that the auditor's role is to detect fraud instead of the audit of the financial statements.

iii. To add to the existing knowledge in the subject matter.

\section{RESEARCH HYPOTHESES}

The following hypotheses seek to answer the research questions:

1. Ho: There is no significant relationship between the role of the auditor and fraud detection in selected firms in Nigeria

2. Ho: There is no significant relationship between fraud detection and audit of the financial statement in selected firms in Nigeria.

3. Ho: There is no relationship between the qualification and experience of the auditors and fraud diction in selected firms in Nigeria

Auditing is an independent appraisal process often governed by statute for examining, investigating and verifying the financial statements of any organization or entity by a qualified person appointed to do the job who seeks to established an opinion concerning the truth, accuracy, validity, reliability and fairness of the statements and the records on which the statements are based and concerned with any statutory or other requirements. 
To make auditing possible, the internal control measures should be adequate and perfect. The accounting system must be sound and the organizational structure must not be overlapping.

According is a set of rules and method by which financial economic data are collected, processed and summarized into reports that can be used in making decisions. Both definitions confirm that it is the tool for decisions making. Decisions could be made on progress of work, continuity or cancellation of certain policies or method arid modifications where necessary. Accounting systems reflect the soundness of an organization. It is the collation and classification of statistical data resulting from the activities of an entity.

Organization's structure should be designed in such a way as to show the activities and financial responsibilities of each department and sections where activities are segmented and span of control is clearly stipulated, the needed checks and balances by the examiner who audits would be made easy.

Responsibility accounting, according to simpson $(1979: 118)$ is concerned to a large extent with the interface between data inputs and the managers who use data. It is the classification of accounting and statistical data resulting from the activities of an agency in such a way that so directly relates them to the control. Auditing and accounting are synonymous as one cannot work in isolation of the other. Hence, there is need to relate the accounting duties of an entity with the various activities within the system and the allied checks and balances of auditing.

\section{ACCOUNTING RECORDS}

Every successful company must keep proper accounting records to monitor its activities to enhance adequate control for the progress of the organization. Accounting records must be designed in such a way as to show and explain the transactions of the company. It should be able to disclose with accuracy, the financial position of the company. It should ensure that financial statements prepared comply with the provisions of the enabling act of the company. It should have the details of the assets and liabilities of the company.

Record according to Chambers (1972:84) is a formal writing of any fact or proceeding. It is a book of such writing. It is past history. It is memorial, it is valuable to keep record for as long as possible for safekeeping and easy retrieval. Accounting records are essential in the progress of an entity. The modern technology has made accounting work easier and faster through the use of computers and electronic calculators. The modern technology, not withstanding the use of record books is still very vital for the auditor's work.

\section{AUDITOR'S RESPONSIBILITIES}

Auditors are born and trained to have inquiring minds, as certain financial statements prepared by the management of an entity may actually not represent the true financial position of the organization.

To provide credibility to retorts and accounts therefore, auditors must examine records available through to detect errors, disclose fraud, detect any from of irregularity or misleading report, evaluate the effectiveness or otherwise of the internal control system in place. Auditing enables the management and investors have correct and efficient information for decisions making sufficient skill and experience. $\mathrm{Bi}$ this becomes unworkable when the numbers of contributors increase.

Auditing is been with us since the sixteenth century when the divorce between those who provided capital and those engaged in business activities began to grow. However, there arose a need for legislation to protect investors from the inefficiency and perhaps deceit of their directors. The mandatory requirement for the audit of company's account and for the presentation of an audit report to members was finally embodied in the companies acts by the twentieth century.

\section{WHY HAVE AN AUDIT?}

Owners (i.e. shareholders) need to gain confidence in the financial report presented by management of their use of the resources entrusted, to them, as the report may contain errors and not disclose fraud, be inadvertently or deliberately misleading or fail to disclose relevant information. In fact, the report could consist of any combination or all of the above anomalies, such confidence as required by the shareholders is essential to the proper functioning of the economy. The audit can said to inspire the confidence which oils the machinery of business and solution to the problem of credibility in the financial reports presented by management to shareholders. In selected firms, the answer to the question of why there should be an audit tends to be simplistic since the company Act says "you must, and provides for substantial penalties if you do no". From the a 
foregoing, therefore the reasons for having an audit are categorized into:

(i) Establishing confidence on the financial statement presented by management and

(ii) Statutory

\section{VARIOUS TYPES OF AUDIT}

(1) Economy and Efficiency: This type of audit attempts to identify whether the entity is managing and utilizing its resources economically and efficiently and addresses areas of uneconomical or inefficient tendencies for management information.

(2) Programme Results: This type of audit identifies whether desired results and objectives are being achieved and recommend alternative where necessary.

(3) Financial and Regularities Audit: this type ensures that system of account and financial controls are efficient and operating properly and transactions have been correctly authorized and accounted for, it is also to verify that expenditure has been incurred or approved services in accordance with the regulations guiding the entity.

(4) Value for Money Audit: this examines whether programmes or project under meets the goals and objectives establishing the entity. Audit types are further classified into:

(a) Statutory Audit: These are auditing carried out in compliance with the provision of the companies and allied matters Act, 1990. It is a compulsory requirement for some selected firms registered under the act.

(b) Non-statutory Audit: these are the ones carried out by the company itself using its own employees. It can be grouped by references to instruction such as complete audit etc.

(i) Complete Audit: This can be described as one in which the auditor is given unrestricted scope as to work which he is to perform and in which he uses his own discretion as to the extent of the detailed work. The auditor may be held liable for anyloss arising through his neglect in any such case.

(ii) Partial Audit: The idea of this means that the auditor is restricted to a particular area of work only or is restricted in any way as to his power of enquiry.

(iii) Continuous audit: A continuous audit is one where the auditor or his staff is constantly engaged in checking the accounts during the which period or where the auditor or his staff attends at regular or irregular intervals during the period.

(iv) Final audit: This is one which is not commenced until after the book have been closed at the end of the financial year or which is only commenced towards the end of the financial year carried through to completion after the end of the year.

(v) Internal and External audit: The basic difference is the body been whose behalf the audit work is concluded. In an external audit, a report is made to a person external to the audited entity especially the shareholder and members of the legislature. In an internal audit, it is an independent appraisal of the activities within an organization for the review of accounting financial statements and other operations basic form for the service to management. It is a managerial control, measuring and evaluating the effectiveness of other operational controls.

(vi) Annual audit and Ad-Hoc: Annual audit is the regular audit usually governed by statute, while ad-hoc audit is as a result of needs for investigation.

(vii) Pre Audit, Post audit and continuous audit: There is distinction between the three types. It depends on the time when the audit is carried out but pre audit is a check before financial transactions takes place. This is to prevent irregular and wrongful expenditure. Continuous audit is the examination of larger entities during the financial year.

Legal implications of auditors: The Companies and Allied Matters Act (1990,CAMA) place the auditor's responsibility with the external auditor whose prime role is to audit the annual balance sheet and profit and loss account of the company. 


\section{DUTIES OF AN AUDITOR}

The auditor's duty is to examine the financial records of the company and to take reasonable care to ascertain that the financial records show the company's true position. The auditor is expected to prepare a detailed report to the company members and the report shall state the matters set out in schedule six to this act. The auditor is also to consider whether the information given in the director's report for the year for which the accounts are prepared is consistent with those accounts; and if they are of opinion that it is not, they shall state that fact in their report. If the subsiding company and its auditors fail to provide this information, every other officer who is in default shall be guilty of an offence and liable to fine.

\section{AUDIT OF ACCOUNTS OF FIRMS}

Audit of the accounts of any limited liability company is provided for by the companies Act and is therefore compulsory.

Extent of examination to be carried out by the auditor cannot be limited. The auditor examines all accounts and has access to all records. Has a right to any information he may require from officials of the company.

(3) The auditor reports to the shareholders in accordance with the provisions of the companies Act. provisions being made in the companies Act for exceptional circumstances.

The auditor is an agent of the shareholders and not of the directors, and therefore reports to the shareholders. It is a misfeasance to report to the directors alone (re: London and general Bank).

the auditor must see that full disclosure of profits and losses is made according to the provisions of the company

The auditor must be a professionally qualified the audit fee must be disclosed in the final accounts laid before the shareholders.

\section{FRAUD}

From the auditor's point of view, "fraud may be broadly classified as deliberate steps by one or more individuals to deceive or mislead with the objective of misappropriating assets of business, distorting organization's apparent financial performance or strength, or otherwise obtaining an unfair advantage".

It may start as a genuine mistake, be successfully covered up and develop there after into a full fledged long-terms fraud.

Alternatively, it may be a "one-time walk in rip-off". It ray engineered from within (i.e. employees or managers or both) or from outside (i.e. business contacts or the general public) or combination of the two. The misappropriation of assets may involve the creation, alterative suppression of accounting records, vouchers and documents, or tampering with equipments (e.g. meters, files, containers) or the misuse of time, property or services.

The distortion of financial performance or position is more concerned with puffing on a good front or window dressing and is usually perpetrated by management using creative accounting. Fraud may occur because responsibility for prevention is not allocated, because dishonesty is accepted as inevitable, known cases go unpunished and the diseases spread; because security is thought too expensive or covered by fidelity bonds.

The main factors contributing to today's accountant, member of the institute of chartered accountants of Nigeria and must hold a practicing certificate. The auditor must not be a director nor an officer of the company nor a partner of an employee of an officer of the company. sed level of fraud included:

- Growing complexity of organizations.

- Ever-increasing speed of modern commerce and computerization.

- History of inattention.

- Understaffing of internal audit functions.

- Acceptance of some level of fraud as the 'cost of doing business'.

- Outdated and ineffective internal controls.

- Aggressive accounting practices.

- Increasingly transient employees.

Prevention of Fraud is a two stage process:

1. Ensure that opportunities for fraud are minimized, (fraud prevention), and 
2. Ensure that potential fraudsters believe they will be caught, (fraud, deterrence).

\section{TYPES OF FRAUD}

\section{False Accounting}

Some of the most dramatic corporate failures over the years have been characterized by false accounting:

i. the main aim of false accounting is to present the results and affairs of the organization in a better light than the reality.

ii. this is often done by overstating assets or understating liabilities to reflect a financially stronger ; the reasons for doing this are varied and include obtaining financing, supporting the share price, and attracting customers and investors.

\section{Asset Misappropriation}

Any business asset can be stolen by employees or third parties, or by employees and third parties acting in collusion.

Examples of common employee and management fraud include:

i. Direct theft of cash or realizable assets, such as stock or intellectual property, such as price or customer lists.

ii. Make false expense claims.

iii. Payroll fraud - diverting payments or creating fictitious employees.

\section{Computer Fraud}

There is no such things as 'computer fraud' per se. Rather, a computer can be the object, subject or tool of a fraud. As technology evolves, so we see new of perpetrating fraud through computers. Such frauds have included:

i. Diverting funds from one bank account to another, having gained unauthorized access to the bank, perhaps by hacking.

ii. Holding out to be legitimate business on the internet and obtaining payment for goods that are not delivered or a lower specification than that advertise

iii. Manipulating the share price of a company by publicizing invalid news items or claims on bulletin boards.
Each of these frauds could have been carried out without the use of computers. What computers and the internet in particular, have provided is access by connected parties, where previously an insider would need to have been involved. Computers also allow processing of large amounts of data to be performed quickly, enabling the creaking of password.

\section{Insurance Fraud}

Insurance fraud covers a number of areas and varies widely in its nature; it includes, but is not limited to:

i. Overstated claims.

ii. False claims losses that never occurred.

iii. Multiple claims.

iv. Obtaining cover on favourable terms on the basis of false information.

\section{Intellectual Property Fraud}

Intellectual property includes items such as patents, design rights and customer lists, and is just as much a business assets as plant a machinery or stock. Like any other asset, intellectual property is therefore, susceptible to theft by staff and third parties, although it is not always apparent intellectual property rights are being misappropriated or infringed.

Employee and management fraud could include direct theft of intellectual property, for example by departing employees using critical business information to set up in competition or through the sale of price lists or ts by existing employees.

\section{6. theft or infringement by third parties}

i. Deliberate under-reporting of royalties by a party selling or manufacturing the product under licence.

ii. Knowingly developing competing products and infringing design rights that have already been registered and protected by the creator.

iii. Passing off fake products as the genuine article, e.g. branded luxury goods, perfumes, CDs and computer software.

\section{Corruption}

General, bribery and corruption are off-book frauds that occur in the form of: 
i. Kickbacks or commission

ii. Bid rigging

iii. Gifts or gratuities

\section{Money Laundering}

Though not a fraud itself, money laundering is closely linked with fraud, as it is the mechanism by which the proceeds of crime are distributed. Examples of such linkage could include:

i. Obtaining ban, loans against assets derived from criminal activities.

ii. Issuing company cheques to third parties and those parties issuing cheques to an individual

\section{Investment Scheme Fraud}

Investment scheme fraud can also be thought of as third-party asset misappropriation. It involves taking money from customers on the promise of spectacular returns but using the cash for one's own purposes.

Such frauds result from a combination of motivational and situational factors in which the crucial element is the presence of both opportunity and motivation. Effective control structures, whether preventive or detection based, can serve to reduce or deny the opportunity to a potential fraudster.

Others includes:

i. Pharmacy Fraud: Dangerous health considerations.

ii. Identity Fraud: Hacking, identity theft, phishing/spoofing, spam, spyware.

iii. Financial fraud: Cross-border fraud, charities fraud, romance schemes, debt elimination, Nigerian "4-1-9" Scams.

iv. Auction fraud: Terminology, international auction fraud, escrow services scam.

Fraud detection: auditors' role: It is not the auditor's purpose in carrying out an audit to determine whether or not frauds of any kind have been perpetrated by servants of his clients. As hope said in Kingston Cotton Mill (No. 2) 1896; (the auditor) does not guarantee the discovery of all fraud.

As has been stated, the auditor's duty is to assess whether or not the published accounts accurately represent the true state of his client's business and to produce report addressed to the owners in which he expresses his opinion of the truth and fairness, and sometimes other aspects of the financial statements. The phrase "true and fair" does not imply that the accounts are correct in every detail and the presence of minor inaccuracy would not invalidate the auditor's opinion. It is however, obvious that if a material fraud has been perpetrated and is not discovered then the published accounts will not reflect the true state of the client's business.

Consequently, auditors make a contribution to the detection of possible fraud even though "reliance on the auditors to detect fraud is misplaced". The first stage of an audit is designed to establish if the accounting records are accurate and provide a reliable basis for the preparation of accounts. This objective can be achieved by checking all the routine transactions which took place during the financial year and this process might uncover fraud, except where fictitious evidence have been carefully created.

However, the cost of such an approach is prohibitive. Fortunately, it possible to reduce the volume of test without greatly reducing the validity of opinion by using sampling technique. Using such an approach almost as likely to detect fraud, which would be found by a far comprehensive examination. But even this approach is also be expensive. As a result, the auditors adopt a different method, which relies extensively upon the organization's system of internal control and internal checks. The essence of the approach is to analyze and evaluate the system and then to carry out tests to establish that the controls are operating intended and constitutes a reliable basis for the preparation of the annual accounts and to determine the required substantive testing.

The examination of the system is usually done with the following fundamental consideration:

i. The possibility of defalcation/fraud, either permanent or temporary.

ii. the possibility of undiscovered errors occurring.

iii. the possibility of accounts being deliberately distorted.

If the internal control is very weak, it may not be possible to express an opinion at all on the accounts presented. If on the other hand the internal control is strong, there could be a minimization of the amount substantive testing used in arriving at an opinion.

The second stage of an audit is much more likely to detect a major fraud. Here, substantive evidence is sought in support of all items appearing in the 
accounts. This evidence is required to show, inta alia that the asset actually exist, that the company has good title to them and that they as correctly shown as regards cost.

Evidence is also required in support of items appearing in the profit and loss accounts. Much of the evidence is derived from documents already in the possession of the company and subjected internal control, but other evidence is derived from physical inspection and direct from their parties.

In carrying out this process, the auditor inevitably concentrates on fib higher value items and those, which are more easily susceptible to misappropriation.

At the final stage of an audit, the search for and examination substantive evidence may contribute to a large extent in detection fraud. The auditor in performing his duty aims at being thorough a systematic, but there is no doubt that some carefully planned and highly ingenious schemes can defeat the most horough and systematic of audits.

Thus quoting from Justice Hope in the Kingston cotton mill case of $1896 "$

"Auditors must not be
liable for not tracking out
ingenious and carefully
laid schemes of fraud
when there is nothing to
arouse their suspicion, and
when those frauds are
perpetrated by tried
servants of the company
and are undetected for
years by the directors. So
to hold would make the
position of an auditor
intolerable".

Though the auditor in carrying out his work should exercise due professional care and reasonable skill but need not approach it with suspicion. However, if he (auditor) is put upon inquiring by anything he discovers during the course of his checks, must investigate it until he reasonably satisfies himself as to the explanation. If material irregularities are discovered, he must report accordingly - either to the directors or to the members as appropriate. It is convincingly clear however, that only irregularities (Perhaps Innocent) and fraud could arouse the auditor suspicion. The courts have had occasions to consider many cases where was held on the facts of those cases that the auditor ought to have be put on inquiry. References to some of these cases, which are in no way definitive, will indicate some of the factors which the auditor ought to consider. In Brown and Wright v. Thompson, Pluckett and co (19939) act 397 , the auditor was held negligent in that on striking the trial balance in successive years, he discovered a deficiency of up to five thousand pounds which he put down to book keeping error rather than tracking down he real cause; namely fraud.

Other areas have been omissions, increasingly or unusually large cash balances, knowledge of dishonesty in a servant and entries made after relevant data which are deemed ought to have put the auditor upon inquiry. The auditor will normally be held liable if in the course of his checks he overlooks some errors, omissions or suspicious circumstances or fails properly to investigate the matter having detected it. If the overall programme of his audit work is reasonable, it is unlikely that the auditor will be held liable if that programme of work did not included the examination of some accounting records or documents which contains some obvious errors on its face which even a most cursory examination must have uncovered. Where the fraud or error does not have effect upon the financial state of the business, it is doubtful that whether the auditor would be held liable where the details of the audit reasonably did not deal with the area of the fraud or error. However, where the fraud or error has a material effect upon the financial state of the business, the onus upon the auditor to show he was acting reasonably in not discovering it will be heavy.

Management's role in fraud detection: "The best protection of a company against fraud and irregularities is an effective system of internal control, and management has the responsibility for developing and instituting these controls, thus they are liable for a faulty system of internal control which permits the perpetration of fraud". Besides, as the auditing guideline on internal controls says, "Management is frequently in a position to override controls which it has itself set up".

Internal control is defined by the same guideline as "The whole system of controls, financial and otherwise, established by the management in order to carry on the business of the enterprise in an orderly and efficient manner, ensure adherence to management policies, safe guard the assets and secure as far as possible the completeness and accuracy of for records. 
This is still meant to get a certain degree of assurance on the system. Errors occur through human or mechanical weakness, but on the other hand a contributing factor may be weakness in the system itself. Where any such weakness does exist in the system of internal control, actual defalcation and fraud may be encouraged

\section{SHOULD AUDITOR'S RESPONSIBILITY INCLUDE SEARCHING}

For fraud?: The auditor has responsibility to plan and perform the audit to obtain reasonable assurance about whether the financial statements are free of material misstatement that could be caused by error or fraud. In a recent survey conducted, Barbara and Franco (1999:46) SAS No. 82, current legislation states that audit has a responsibility to perform audit to detect error or fraud. Sixty-one percent of the seventy respondents disagreed that they should be responsible for searching for fraud.

However, the low response level could not be a correct representation of the population their findings can only be taken as suggestive. It could be argued that since the financial statements prepared by the management of an enterprise may not represent the financial position of the organization the need to have independent professional opinion to shed light on study areas is paramount.

\section{RESEARCH METHODOLOGY}

The research design used is both explanatory and descriptive in nature involving collections, analysis and interpretations of data with a view to evaluate the roles of auditor in fraud detection and prevention in selected firm in Nigeria

Population and sample size: According to Ngagi (1998:81), a population is the entire group whose characteristics are to be estimated. Population is sometimes referred to as the universe. A representative group is used to ensure that data collection provides unbiased; suitable and close estimates of the characteristics the sampled population.

The sample for this study includes fifteen firms randomly selected. They are:
1. Nigeria Bottling company Plc
2. Guinness Nigeria plc.
3. Zenith Bank Nigeria Plc
4. Union Bank Nigeria Plc.
5. Machellin Nigeria Plc.
6. Dangote flour Mills Nigeria Plc.
7. Lever Brothers Nigeria Plc.
8. Drug Field Pharmaceuticals Nigeria PIc.
9. Intercontinental Bank Plc.
10. University Press Nigeria Plc.
11. PZ Plc.

Sources of data: Designing a research plan calls for appropriate decisions on data sources so as to enable drawing of conclusion on the subject matter researched. Spiegel (1999:37). Questionnaire Administration and Secondary data used in the study was extracted from text books and, publication journal, articles, seminar and notes etc.

Data collection technique: The main research technique used for this study is questionnaires wile face to face oral interviews of some of those included in the sample was also supportive. The interview method was inevitable as some questions required narrative answers and the respondents were perceived as too busty to go into the task of lengthy writing. The responses obtained through these techniques were considered in the appropriate areas of this study.

Data analysis techniques: the techniques used in the analysis of data for the pose comprehension included simple tabulations, percentages and averages chi-square $\left(X^{2}\right)$ was used at $5 \%$ level of significance to test the hypothesis. Where $X^{2}=\Sigma(0$ $E)^{2}$. The purpose of this test is to determine how well an observed set of data $E$ fits an expected set

When $\mathrm{X}^{2}=$ Chi-square

$$
\begin{aligned}
& O=\text { Observed frequency } \\
& E=\text { Expected frequency }
\end{aligned}
$$

\section{Presentation and analysis of data}

\subsection{HYPOTHESIS TESTING}

After analyzing the responses of the questionnaire, thus aspect tested the research hypothesis with the prescribed test statistics. The statistics is chi-square.

$$
\mathrm{X}^{2}=\frac{\sum(0-E)^{2}}{\mathrm{E}}
$$

Where $\mathrm{X}^{2}=$ Chi-square

$$
\mathrm{O}=\text { Observed frequency or data }
$$


$\mathrm{E}=$ Expected frequency or data. Source: Agbadudu (1994:170)

Decision rule: we accept $H_{0}$ when cal $X^{2}<T a b X^{2}$, otherwise we reject $\mathrm{H}_{0}$

\section{HYPOTHESIS I}

There is no significant relationship between the role of Auditors and fraud detection and investigation in selected firms in Nigeria.

Table I: Relationship between the role of auditors in fraud detection

\begin{tabular}{|l|c|c|}
\hline Responses & $\begin{array}{l}\text { Number of } \\
\text { respondents }\end{array}$ & \% \\
\hline Yes & 32 & 76 \\
\hline No & 10 & 24 \\
\hline Total & 42 & 100 \\
\hline
\end{tabular}

Source: Fieldwork, 2010.

\section{Analysis}

32 respondents representing $76 \%$ said yes while 10 representing $24 \%$ said No.

Table 2: Computation of chi-square

\begin{tabular}{|l|l|l|l|l|l|}
\hline Responses & $\mathbf{0}$ & $\mathbf{E}$ & $\mathbf{0}-\mathbf{E}$ & $\mathbf{( 0 - E ) ^ { 2 }}$ & $\mathbf{E ( \mathbf { 0 } - \mathbf { E } ) ^ { 2 }}$ \\
\hline Yes & 32 & 21 & 11 & 121 & 5.76 \\
\hline No & 10 & 21 & -11 & 121 & 5.76 \\
\hline Total & 42 & 42 & & 242 & 11.52 \\
\hline
\end{tabular}

\section{Source: Derived from table 1}

Ho: $\quad \mathrm{P}_{1}=\mathrm{P}_{2}$

Ha: At least one of the equation does not hold.

$$
E=\frac{42}{2}=21
$$

The Cal $X^{2}=11.52$

$$
\mathrm{X}^{2} 1 \mathrm{k}=1
$$

When $\mathrm{a}=5 \%$ when $\mathrm{K}-1-$ degree of formular

$$
\mathrm{X}^{2} 2=1
$$

$$
1-0.05
$$

$\mathrm{X}^{2} 1$

1-95

$X_{1-.95}^{2}=9.49$

At $5 \%$ level of significance and 1 degree of freedom, tab $X^{2}=9.49$ while Cal $X^{2}=11.52$

\section{Decision Rule}

Since from the above, Cal $X^{2}$ of 11.52 exceeds tab $X^{2}$ of 9.49 we will therefore, reject the null hypothesis and accept the alternative hypothesis.

\section{Decision}

This means that there is a very significant relationship between the role of auditors and fraud detection and investigation the organization in the organization.

\section{HYPOTHESIS 2}

There is no significant relationship between fraud detection and audit of the financial statements in selected firms in Nigeria

Table 3: Relationship between fraud detection and the audit of Financial Statements in Organisations.

\begin{tabular}{|l|c|c|}
\hline Responses & $\begin{array}{l}\text { Number of } \\
\text { respondents }\end{array}$ & \% \\
\hline Yes & 40 & 62 \\
\hline No & 2 & 38 \\
\hline Total & 42 & 100 \\
\hline
\end{tabular}

Source: Fieldwork, 2010.

\section{Analysis}

40 respondents representing $62 \%$ said yes while 2 representing $38 \%$ said No. 
Table 2: Computation of chi-square

\begin{tabular}{|l|l|l|l|l|l|}
\hline Responses & $\mathbf{0}$ & $\mathbf{E}$ & $\mathbf{0 - E}$ & $\mathbf{( 0 - E ) ^ { 2 }}$ & $\frac{\mathrm{E}(\mathbf{0}-\mathrm{E})^{2}}{\mathbf{E}}$ \\
\hline Yes & 40 & 21 & 19 & 361 & 17.1 \\
\hline No & 2 & 21 & -19 & 361 & 17.1 \\
\hline Total & 42 & 42 & & 722 & 34.2 \\
\hline
\end{tabular}

Source: Derived from table 3

Ho: $\quad \mathrm{P}_{1}=\mathrm{P}_{2}$

Ha: At least one of the equation does not hold.

$E=\frac{42}{2}=21$

The Cal $X^{2}=11.52$

$\mathrm{X}_{1-\mathrm{a}}^{2} \mathrm{k}^{\mathrm{a}}=1$

When $\mathrm{a}=5 \%$ when $\mathrm{K}-1-$ degree of formular

$\mathrm{X}^{2} 2=1$

$\begin{array}{ll}X^{2} 1 & 1 \\ 1-95\end{array}$

$\mathrm{X}_{1-.95}^{2}=9.49$

At $5 \%$ level of significance and 1 degree of freedom, tab $X^{2}=9.49$ while Cal $X^{2}=34.2$

Decision Rule: Since from the above, Cal $X^{2}$ of 9.49 , is lower than Cal X2 $=34.2\left(\mathrm{cal} X^{2}>\operatorname{tab} X^{2}\right)$ we will therefore reject the null hypothesis and accept the alternative hypothesis.

Decision: This means that there is a very significant relationship between fraud detection and audit of financial statements in the organization.

\section{HYPOTHESIS 3}

Table 4: Relationship between the qualification and experience of the auditor and his ability to detect fraud.

\begin{tabular}{|l|c|c|}
\hline Responses & $\begin{array}{l}\text { Number } \\
\text { respondents }\end{array}$ & of \\
\hline Yes & 32 & 76 \\
\hline No & 10 & 24 \\
\hline Total & 42 & 100 \\
\hline
\end{tabular}

Source: Fieldwork, 2007.

Analysis
32 respondents representing $76 \%$ said yes while 10 representing $24 \%$ said No.

Table 2: Computation of chi-square

\begin{tabular}{|l|l|l|l|l|l|}
\hline Responses & $\mathbf{0}$ & $\mathbf{E}$ & $\mathbf{0}-\mathbf{E}$ & $\mathbf{( 0 - E ) ^ { 2 }}$ & $\frac{\mathbf{E}(\mathbf{0}-\mathbf{E})^{2}}{\mathbf{E}}$ \\
\hline Yes & 32 & 21 & 11 & 121 & 5.76 \\
\hline No & 10 & 21 & -11 & 121 & 5.76 \\
\hline Total & 42 & 42 & & 242 & 11.52 \\
\hline
\end{tabular}

Source: Derived from Table 4

Ho: $\quad P_{1}=P_{2}$

Ha: At least one of the equation does not hold.

$E=\frac{42}{2}=21$

The Cal X $X^{2}=11.52$

$\mathrm{X}_{1-\mathrm{a}}^{2} \mathrm{k}=1$

When $\mathrm{a}=5 \%$ when $\mathrm{K}-1-$ degree of formular

$x_{1-0.05}^{2}=1$

$X_{1-95}^{2}$

$\mathrm{X}_{1-.95}^{2}=9.49$

At $5 \%$ level of significance and 1 degree of freedom, tab $X^{2}=9.49$ while Cal $X^{2}=11.52$

Decision Rule: From the above, Cal $X^{2}$ exceeds tab $X^{2}$ and since cal $X^{2}>$ tab $X^{2}$, we will therefore reject the null hypothesis and accept the alternative hypothesis.

Decision: This means that there is a very significant relationship between the qualification and experience if the / auditor and his ability to detect fraud in the organization.

\section{SUMMARY}

The findings are as follows:

1. These companies produced and published financial statements and these organizations engage the services of auditors.

2. that there have been cases of fraud in these organizations due to poor management, lack of internal auditors, inefficient internal control system corruption.

3. the study also reveals that there is a very significant relationship between the role of 
auditors and fraud detection in selected firms in Nigeria.

4. Also, that there is a very significant relationship between fraud detection and the audit of financial statements in selected firms in Nigeria.

5. And finally, that there is a positive relationship between the qualification and experience of the auditor and fraud detection and investigation in selected firms in Nigeria.

\section{CONCLUSION}

Based on these findings, it is therefore concluded that although the selected firms produced and published financial statements and also services of auditors, there are still cases of fraud due to poor management, non engagement of the services of external auditors poor internal control systems and corruption generally.

It is also concluded that the role of auditors can lead to fraud detection in the financial statements of selected firms and also that the qualification and experience of auditors play a major role in fraud prevention and detection in these organization.

\section{RECOMMENDATIONS}

1. It is therefore recommended that selected firms should ensure policies and strategies aimed at effective management.

2. Also recommended is that management should continually engage the services of qualified and experienced external. Auditors which will not only put in place an effective internal control system but which will equally enhance it.

3. finally, education, proper enlightenment and self-discipline is recommended to step down the level of corruption not only in selected firms but also in Nigeria as a whole.

\section{REFERENCES}

Adeniyi, A.A.. (2004), AUDITING And Investigation. Value Analysis Consult, Lagos.

Agbadudu, A.B. (1994), Statistics for Business and the Social Sciences, Uri Publishing Ltd., Benin City, Edo State.

Alvin, A.S. \& James, K.L. (1984), Auditing And Investigation Approach. Longman Group Limited, London.

Asika, N. (1991), Research Methodology in the Behavioural Sciences. Longman Nigeria Plc, Lagos State.

Baridam, D.M. (2001), Research Methods in Administrative Science. Third Edition, Associates, Port Harcourt.

Clive de Paula, F. and Attwood, F.a. (1983), Auditing Principles and Practice. Sixteenth Edition., Pitman Book Limited, London.

Companies and Allied Matters Decree (1990), Federal government Printers, Lagos.

Howlard, R. (1982), Auditing Seventh Edition, Macdonald and Evans Limited, London.

Millichamp, A.H. (2002), Auditing. Eight Edition, Continum Tower Building, New York.

Ngagi, J.O. (1999), Essentials of Research Methodology for Educators, University Press Plc. Ibadan.

Okolo, J.U.t. (2001), The concept and Practice of auditing. Evans Brothers Nigeria Limited, Ibadan.

Omorokpe, R.O. (2003), Dictionary of financial Accounting terms. Mindex Publishing Company Limited, Benin City.

Osemwota, et al, (1996), Research and Statistical Methods. Amfitop Book, Lagos.

Porter, W.T. and Borton, J.C. (1971), Auditing: A Conceptual Approval. Wadsworth Publishing Company, California.

Pratt, M.J. (1982), Auditing Longman Group Limited, London.

Santock, J. (1978), Case studies in auditing. Second Edition, Macdonald and Evans Limited, London.

Spiegel, M.R., Stephens, L.J. (1999), Statistics. Third Edition, McGraw-Hill, London. 